\title{
Introduction to the special issue: Media responsibility and accountability
}

\author{
LEEN D'HAENENS and JO BARDOEL
}

Before you lies a special issue which deals with the social responsibility of the media within the triangle of multiple spheres of influence of the government, the market, and civil society. Background is the breakdown of institutional safeguards in broadcasting, and of professional agreements in the press through the concentration of ownership and the influence of owners' views in news coverage. In turn, these breakdowns lead to a considerable decrease in public credibility of newspapers, as shown in a recent Canadian study by Stuart Soroka and Patrick Fournier ${ }^{1}$. Furthermore, this survey revealed that many Canadian journalists quasiunanimously mistrust the concentration of newspaper ownership; more than half of them (56 per cent) believe that their owners' views and interests are indeed regularly reflected in the content of their newspaper. Editorials are seen as most frequent vehicles for these influences. Similar trends can be noticed in the press sector on the other side of the Atlantic. In the European context, most attention goes to the rapid changes in the broadcasting landscape, where the monopoly of public broadcasting has been replaced by 'dual' broadcasting structures in which commercial broadcasters have taken the lead and public broadcasting is forced into the defence. Consequently, public broadcasters have to redefine their mission in relation to the new, national and European policy and market parameters. All in all, this means that in the present-day media field the public interest and indeed the interests of citizens are at stake.

One of the central questions raised in this special issue is therefore; how can the interest of the citizens be given a voice by making the media sufficiently accountable? We will start our 'tour d'horizon' with the academic reflection upon and conceptualization of notions that are central to this question. It soon becomes clear that a single uniform theory of the media's social responsibility simply does not exist. The concept of responsibility refers to media content as well as to its function in society. Social responsibility is interpreted in terms of both 'responsibility,' indi- 


\section{Leen d'Haenens and Jo Bardoel}

cating the media's responsibility regarding society, and 'responsiveness,' referring to the manner in which the media listen to and consider the public. The recently increased interest in the social responsibility of the media is certainly related to structural developments in the media sector itself, which have formed strong enough a basis for this feeling of urgency.

Throughout Western Europe over the last fifteen years, a dual broadcasting system has come into existence in which public broadcasters operate alongside commercial competitors. This media reality, characterized by competitiveness, contains ever more commercially-run media corporations in both the profit and non-profit sectors, which has resulted in a greater mixing of genres as far as media content and syntax are concerned (infotainment, docudrama, reality TV, etc.). In 2004 we no longer think of 'The Media' as independent press organizations of different political or ideological convictions, but as one large media industry, with media barons such as Rupert Murdoch, Sylvio Berlusconi, Conrad Black or the late Izzy Asper at the forefront. We do not associate 'The Media' primarily with press organizations but rather with television and the Internet, media which do not dedicate themselves first and foremost to the transmission of knowledge and information, but rather to the provision of entertainment, sensation, and news framed in terms of conflict and emotion, leaving the audience in 'shock and in awe' ...

With this development, broadcasting is in fact following in the footsteps of the print media, which have always been exposed to the logic of the market, and where in recent decades the old traditions of the trade which contained the necessary room for newspaper journalists and cultural considerations - have given way to modern entrepreneurship and 'shareholder value.' According to many scientific observers, the societal changes that have led everywhere to a predominantly commercial management of the media are of such a nature that the traditional legal and market-oriented accountability mechanisms alone are no longer sufficient.

Or, as stated by Ignacio Ramonet in an editorial in Le Monde Diplomatique $^{2}$ :

"Les appétits carnassiers des nouveaux empereurs de la communication poussent d'autres publications à rechercher une taille critique afin d'échapper à une prise de contrôle. (...) Toutes ces concentrations menacent le pluralisme de la presse. Et la démocratie. Elles conduisent à privilégier la rentabilité."

Like many such collections of articles, this special issue began at a conference held on March 28, 2003, at the University of Antwerp, initiated 
by the Flemish Association of Canadian Studies and the Jean Monnet European Center of Excellence for the Interdisciplinary Assessment of Initiatives for Public Governance, at the University of Nijmegen. The title of the expert meeting was "Media in Dynamic Interaction with Government, Market and Citizens. Interdisciplinary evaluation of initiatives of responsibility and accountability in the media in Belgium, Canada and the Netherlands". Given the intention of this conference - offering an inventory of theories and practices - and the broadness of the subject, a certain measure of 'incoherence' was inevitable. Nevertheless, all articles are animated by a central preoccupation and a common sensibility. Four of the six articles were presented at the expert meeting and were rewritten for this special issue; one was not presented then but established the basis for the venue and expressed the common concerns (Bardoel and d'Haenens); one was freshly made for this issue (van Summeren and d'Haenens).

The present collection of articles is twofold; the first three articles are academic reflections upon notions of media governance, media responsibility and accountability at the level of the media institution as well as that of specific media genres. The second series of articles looks at concrete media settings. All three provide an inside perspective; from a particular media accountability mechanism, such as the Lincoln Report, on Canada's broadcasting; through views of Canadian media professionals on what could be done to the highly disturbing degree of concentration of the Canadian newspaper market; and by way of the self-reflectory exercise of the Dutch public broadcasting organization BNN aimed at youngsters, as part of its preparation for the visitation procedure that took place in 2003 .

More in particular, Jo Bardoel and Leen d'Haenens offer an overview of recent conceptualizations of media responsibility and accountability, and related concepts such as (media) governance. Equally interesting is the presentation of both internal and external media accountability practices throughout Western Europe and across the Atlantic. Luc van Liedekerke discusses the criteria for corporate governance and their usefulness in media companies. Departing from the corporate governance concept, concentrating on the economic role of media firms, he looks into the concept of good governance, reserved for the interaction between politics and the media, all steering institutions included. Finally, the much broader concept of corporate social responsibility is launched which encompasses the interaction between the media firm and society in terms of identity-building and value formation. Based upon the concepts of 'emancipatory politics' and 'life politics' by Anthony Giddens, Hans Verstraeten explains the role of the media in this process of transformation and the implications for media assessment and accountability. The au- 


\section{$4 \quad$ Leen d'Haenens and Jo Bardoel}

thor proposes to broaden the usual scope from the purely informative genres to the infotainment formats and indicates new avenues in the development of criteria according to which this relatively new genre can be evaluated.

Looking at concrete media contexts, Marc Raboy and David Taras illustrate the interesting model of a long tradition of public consultation Canada is offering. The authors served as expert advisors to the Parliamentary Standing Committee on Canadian heritage for its broadcasting study conducted in 2001-2003. The article discusses some highlights in the landmark study, the Lincoln report, made public mid-2003 as a result of public consultation rounds, and looks into the government's subsequent, somewhat disappointing, response. Petty Bozonelos looks into Canada's newspaper business and asks media professionals what new mechanisms should be urgently put in place in order to control Canada's blatant newspaper concentration, and what role the government and the media profession should play in this. The last article by Cindy van Summeren and Leen d'Haenens deals with a specifically Dutch requirement for public broadcasting organizations to obtain a broadcasting license, the membership requirement, and argues that the criterion of permanent membership is hardly attainable for BNN in the long run. In light of performance criteria considered relevant in e.g., European media policy-making, it is argued that there are objective criteria, both qualitative and quantitative, other than the membership figure requirement that should be taken into account in order to decide upon the future of a broadcaster. Ultimately, BNN fulfils a crowbar function in denouncing the lack of viability of the membership figure requirement in the Dutch public broadcasting system.

\section{Notes}

1. Soroka, S. and Fournier, P. (2003). Newspapers in Canada Pilot Study. Survey Results. Available at [http://www.misc-iecm.mcgill.ca/media/results.htm] (consulted on December $\left.1^{\text {st }}, 2003\right)$. The results were presented at a conference in Montreal, entitled Who Controls Canada's Media? from February $13^{\text {th }}$ to $15^{\text {th }}$. During the month of January 2003, a one-page survey was mailed to some 1000 journalists working at nine mainstream newspapers throughout the country and across a variety of news desk jobs. A total of 360 journalists returned the questionnaire.

2. Ramonet, I. (2002, December). Médias concentrés. Available at [http://www.mondediplomatique.fr/2002/12/RAMONET/17221] (consulted on December $1^{\text {st }}, 2003$ ). 